\title{
密ガラスの强さと割扎方 (1)
}

\section{杉汇重 誠}

\section{I. 緒 言}

\section{1. 試騂の目的}

フルコール式 (Fourcault) 引上法によつて製造される厚さ $2 \mathrm{~mm}$ （俗に並厚といふ）及び $3 \mathrm{~mm}$ の窓ガラスの物理的强度の一つとして 彎曲强度 (Bending strength 又は Breaking strength)を測定し， 同時にその空ガラス試片の彎曲の度合と, 割れの狀態や形等をも記 錄し，强さと彎曲と割れの狀態を種々の方面から試驗し，且つそれ ら相互の關係を考察して見た．而して本試驗に使用したる試片の製 浩時の條件々試驗結果とを種々の觀點から綜合考察した結論から， フルコール式窓ガラスの品質鑑別を少しでも明確にし，更にこれを 以てフルコール式空ガラス製造の諸條件を明暸にせんとしたのであ る. 佾この試驗結果を終始綜合すれば，建築材料として重要なる位。 置を占める空ガラスの使用設計に適切なる實際指示を提供するとこ ろもあららかと考へ，窮極に於て資源愛護と物資活用の目的を達成 するに役立てば幸なりとしてこの試驗を行つたのである.

この測定及び試驗に使用した試片の總數は約 4,000 枚であるが, 試驗結果として得られたその夥しい數字を詳細に記載し說明するの は却つて讀者にとつて煩はしい事であるから，試驗の內容を分り易 く項目に分類し，出來る限り簡單に本均結果だけを記載し，試驗結 果の大要を報告するにとどめた

本報告の內容は些か廣沉に互り，しかも科學的探究の淺いのは, 本試驗の目的が學術研究にあるのでなくして, 製造工場の實際作業 に何等かの害用的指示を與へんとするところにあつたからである. それ故に讃者は本報告に對しては學術論文としてではなく，謂はば 實用的な工業試驗報告として御批判御此正あらんことを乞ふ.

\section{2. 測定の方法}

試片の支へ方はすべて free support の法をとつた. 渮重は試片 の中心郎ち支點間の中央に上から一點で加へ，その荷重(壓力)はス プッングの壓縮を以てし，その壓縮を讀んで荷重を換算する方法を 用みた. スプリングの壓縮は手動式の車で一定の速さで連續的に行 ひ，試片が破碎すると同時に車の迴轉をやめてスプッングの凨縮を 指針で讀み取るのである，加匼は金屬の尖端を以てした。

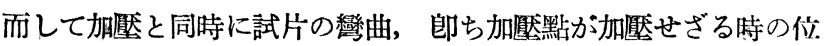
置から，試片が割れる瞬間采でに降下した距離をも讀み取る如き簡 單な裝置をも付けて記錄した。

かやラにして試驗片が破碎した瞬問の荷重郎ち破碎限荷重から， 次式によつて彎曲强度を計算した。
$b$ 試片の幅 $(\mathrm{mm})$
d 試片の厚さ $(\mathrm{mm})$
$l$ 支點間隔 $(\mathrm{mm})$
IV 破碎限荷重 $(\mathrm{kg})$
$B$ 彎 曲 (mm)

$$
\text { 彎曲强度 }=\frac{3 W l}{2 b d^{2}} \mathrm{~kg} / \mathrm{mm}^{2}
$$

佾空ガラスの彈性率 (Modulus of Elasticity. Young's Modulus は彎曲强度と密接なる關係にあり, 試片の彎曲を測れば次式を以て 計算することが出來る.

$$
\text { 彈性率 }=\frac{l^{3} W}{4 b d^{8} B} \mathrm{~kg} / \mathrm{mm}^{2}
$$

この試驗では試片の幅 $5 \mathrm{~cm}$, 支點間隔 $30 \mathrm{~cm}$, 而して支點間の中 央に加節して測定した．特別に記載なきものはすべてこの條件で試 驗したのである.

空ガラスの彎曲强度は荷重を加へて行く速さによつて違つた值を 示すものであり，速ければ强度は大きく現はれ，遲ければ小さく現 はれるものである. (F W. Preston, J. Am. Ceram. Soc.; 1935, 18 220) 然し加壓速度の最も正しい時間は定め難い性質のものであるか ら, 本試驗に於ては試驗裝置との關係をも考慮し, 加厴の速さを平 均 $0.3 \mathrm{~kg} /$ 秒 程度とした. 從つてこの程度の速さで荷重を加へて行 くと, 强度小なる試片は凡そ 10 秒位で割れ, 强度大なるものは 20 秒位で破碎する，佮大形試片は少くとも30 秒位までには破碎して 試驗が完了する.

\section{3. 試片の採取}

本試驗の試片に使用したるフルコール式空ガラスは，連續引上げ たるままの幅は凡そ $2.5 \mathrm{~m}$ 乃至 $1.2 \mathrm{~m}$ であつて, これは引上げに使 用するデビトースのスロットの長さによるのである. 而してフルコ 一ハ法によつて引上げられたる空ガラスには表面の光澤, 本坦さそ の他の外觀に於て表裏の區別は少しもないのであるが，本試驗報告 に於ては，引上げられる時その熔融盧に向つてみる面を便宜上“裏” とし，熔融蠦の外側に向いてるる面を假りに“表”と呼ぶことにし た. フルコール空ガラスに付けたこの表裏の呼稱は, 商品として實 際使用せらるる場合には全く必要なきことであつて，ただ本試驗に 於てその區別を必要とする䉆に付けたものである.

或る一つの事項に對する比較試驗を行ふ場合には必ず大形の同じ 一枚のガラスか一組の試片を切り取つて使用し, 又ガラスの條件が 同一であることを必要としない場合でも，必要な條作だけはよく揃 のる樣にして試片を集めるなど，すべて試驗に用るる試片はその試 驗目的に副ふ樣に極力注意を拂つて取りまとめ，決して製造時期等 の條件不明な試片は使用しなかつた.

本試驗に使用した試片は總て悉くフルコール窓ガラス製造工場に 於て著者自身探取したものであり，從つて本試驗の試片か製造され た時の條件は悉く著者の手元に記錄されてるる.

試片の探取切斷には普通一般に使用されてるる型のダイヤモンド ガラス切り(カッター)を使用した. 然しカッターで切るといふても， カッターで搔き痕をつけその切目に沿ふてガラスを折るのであるか ら, カッターの使ひ方に慣れぬ場合やカッター不良の時, 或はカッ ターの當て方が强過ぎると，折つたあとの切り口が細かい鋸莮狀を 呈し易く，かかる切口には無數の細かいヒビが出來てるると考へら れ, 從つて强度測定の際切口のヒビから早く割れて本當の强度より 低い值を示すことになるのは當然である。

かやうなダイャモンドカッターで切つたままの試片では本當の强 度は得難いといふっので，切口をガス火で融かし或は切口を研磨して ヒビを除いた試片で測定した報告も發表されてるるが，（A. J. Holland, W. E. S. Turner; J. Soc. Gla s Tech., 1936, 20, 72 \& 279) 然し實際の試驗に當りあらゆる事項に就て何千枚の試片を研磨する 
ことは容易ならず, しかもダイヤモンドカッターで熟練を以て注意 深く出來るだけ輕く切れば常に美しい切口になり, その程度であれ ばいつも殆ど一定した結果が得られ，且つ本試驗の目的の範圍に於 てはこれで充分である事を確かめたから，本試驗に使用した試片は すべてダイヤモンドカッターで著者自から一定の方法で切斷したも のである．倘試片切口の狀態から强度にどんな影響を及ばすかは第 11 項を參照されたい。

\section{4. 試片ガラスの化舆組成}

本試驗を行つてるる間のガラス組成には著しき變更を加へたり， 或は變化を起したりしたことなく，實際作業の關係から各成分の間 に些少の變動はあつたけれども大體に於て次の如き組成が基準にな つてるたから，本報告の試片の化學組成はすべて殆どこの䇥園の为 のである.

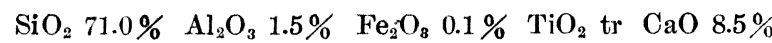

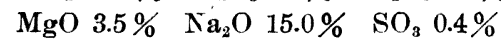

たまたま或る時アルカリ成分がこの基準より多くなり，他の成分 の問に變動を示した試料を得て，その强度を試驗して見たが，本常 組成の試片と何等相違するところが無かつた (38 項參照).

それ故に本試驗全體を通じガラスの化學組成の如何 と强度との關 倸に就ては何子實驗的考察を加へることをしなかつた.

\section{5. 用語の詮解}

この報文に記載した文意の解釋に誤解なからしめんが焉に報文の 中に使用せる用語に就て念の䉆に注解をつけて置く.

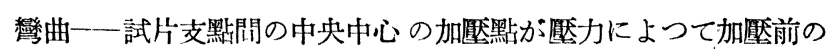

水平位置から破碎するまでに降下した距離.

厚さ一寸べて加厴點の附近郎ち試片の中心附近の厚さである.

荷重一一表の記載を成るべく簡略にするため試片の破碎限荷重を

略して單に荷重と記載した。

强度一一同樣に表の中では彎曲强度を略して單に强度と記載した. 透板一一製造及び販賣者の間では透明な窓ガ ラスのことを俗に透

板（すきいた）と云ふ。

摺板一一同じく摺り空ガラスのことを俗にすりいたと云ふ。

並厚一普通のところに使用されてるる空ガラスの厚さをナミア ッと云ふ. $2 \mathrm{~mm}$ 前後の厚さに當る.

\section{II. 透 板 の 部}

第 1 阔 試片の探り方とその制れの 狀態 (第 15 项, 第 16 項參照)

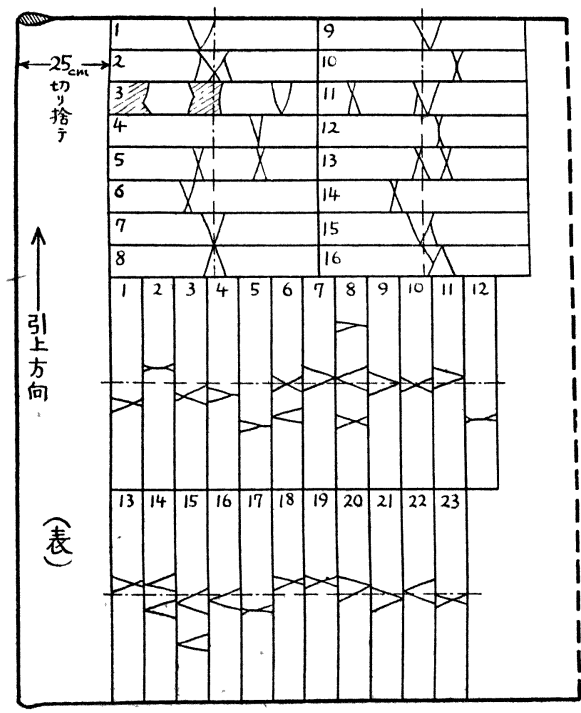

6. 密ガラス試 片の强度の不同

\section{偏差}

空ガラスの彎曲强

I 度は決して一致した 值が得られない。た 、 と一同一枚の大きな 窓ガラスから順次採 取した試片について 浃して一定の强度 數值を示さない.

(W. H. Hampton, C. E. Gould. J. Soc. Glass Tech., 1934, 18, 194) 相糔る位置 から探つた驗片の間 にも著しい差のある ことは空ガラスに於
ては普通の事であつて, その强度の偏差の程度や本均强度と各試片 强度との開きはどんな風であるかを實測の結果を以て次に示す.

この試驗には先づ出來るだけ厚さに不同のない且つ表面歪曲なき 平坦な無疵の大形空ガラスを一枚撰り出し, その一枚ガラスから第 1 圖の如き順序に 18 枚の試片を連續切斷じて探りこれを探取の順 に試驗したのである.

\begin{tabular}{|c|c|c|c|c|}
\hline 武片の幅 & $5 \mathrm{~cm}$ & 支點間隔 & $30 \mathrm{~cm}$ 加厴面 & 表 \\
\hline 試片顼 & $\begin{array}{l}\text { 厚 } \\
\mathrm{mm}\end{array}$ & $\begin{array}{c}\text { 彎 曲 } \\
\mathrm{mm}\end{array}$ & 荷 $\underset{\mathrm{kg}}{\text { 重 }}$ & $\begin{array}{c}\text { 强 度 } \\
\mathrm{kg} / \mathrm{mm}^{2}\end{array}$ \\
\hline 1 & 1.94 & 8.5 & 2.905 & 6.94 \\
\hline 2 & 1.94 & 13 & 4.665 & 11.12 \\
\hline 3 & 1.94 & 9 & 3.345 & 8.00 \\
\hline 4 & 1.93 & 11 & 4.225 & 10.20 \\
\hline 5 & 1.93 & 9.5 & 3.345 & 8.08 \\
\hline 6 & 1.93 & 11.5 & 4.225 & 10.20 \\
\hline 7 & 1.93 & 13 & 4.665 & 11.25 \\
\hline 8 & 1.93 & 12 & 4.370 & 10.55 \\
\hline 9 & 1.92 & 9 & 3.200 & 7.83 \\
\hline 10 & 1.91 & 13 & 4.665 & 11.50 \\
\hline 11 & 1.91 & 10 & 3.780 & 9.32 \\
\hline 12 & 1.91 & 12.5 & 4.810 & 11.85 \\
\hline 13 & 1.91 & 10.5 & 3.780 & 9.32 \\
\hline 14 & 1.91 & 13.5 & 4.960 & 12.22 \\
\hline 15 & 1.91 & 11.5 & 4.225 & 10.40 \\
\hline 16 & 1.91 & 7.5 & 2.905 & 7.16 \\
\hline 17 & 1.91 & 10.5 & 4.080 & 10.10 \\
\hline 18 & 1.91 & 14.5 & 5.400 & 13.32 \\
\hline 本 均 & 1.92 & 11.1 & 4.080 & 9,96 \\
\hline
\end{tabular}

この場合試片の厚さは $1.94 \mathrm{~mm}$ から $1.91 \mathrm{~mm}$ まで僅かに $0.03 \mathrm{~mm}$ の差を有するに過ぎないのに各試片の强度は最小 $6.94 \mathrm{~kg} / \mathrm{mm}^{2}$ から 最大 $13.32 \mathrm{~kg} / \mathrm{mm}^{2}$ までに互り不同を示してるる. 殊に相隣る二枚の 試片を見ても決して同じ强度を示寸ものが無いのは全く奇異である 斯る强度の不同は古くからどの文獻にも報告されてるることであつ て, 或る文獻では强度不同の原因をその試片切口の疵にあると推察 し，切口を更に熔融するか又は研磨して物理的な微細なキレッを悉 く除去した試片について試驗した人もあるが，結果は矢張り同じ樣 な不同を示したと報告されてるる.

斯くの如く著しい不同のあることは，空ガラスには一定の彎曲强 度が無いといふ意味にもとれるし，假りにこの本均值 $9.96 \mathrm{~kg} / \mathrm{mm}^{2}$ を以てその强度を示すとしてり，それは元の大形一枚ガラスを，18 枚の小試片に分割測定した結果の本均值であつて, 決して元の大形 一枚ガラスのその强度を示すものとは考へられないのである. 從つ て悹ガラスを實際使用する際に必要な强度數值は或はそのうちの最 低値一ここでは $6.94 \mathrm{~kg} / \mathrm{mm}^{2}$ 一であるとする考は, 決して無茶な 話ではないとも云へるのである. それ故にこの意味から實用上これ を空ガラスの强度と云はないで, 寧ろ空ガラスの弱度と云ふ方が或 は本當かも知れない.

然らばかかる强度不同の原因或は理由はどこにあるかと云ふ問題 は從來色々の方面で調査研究されてるるのであるが，これといつて 明確な解決がまだ與へられてるない. (A. J. Holland, W. E. S. Turner. J. Soc. Glass Tech., 1436, 20, 279) 同一枚のガラスから僅 か $5 \mathrm{~cm}$ 幅に切り探つた相隣る試片の强度に, かかる相違を示寸原 因として想像されるものは凡そ次の通りである.

（イ）試片の形狀寸法 (口) 加厭法の相違（ハ）試片の探 り方位置（二）試片切口の狀態（ホ）試片ガラス表面にあ る疵（へ）試片の表裏（ト）試片の厚さの相違（チ）試 片ガラス內の雪

即ち誰でも考へつくところはこの樣に項目は多く範圍もひろくて甚 
ゲ複雜であるやうに思はれる，本試驗に於ては些かこの問題にも觸 れて考察を加へて見た．即ち以下第 16 項までは夫々この問題の解 答に何等かの暗示を與へるところのものであらうと思ふ。

\section{7. 試片の大きさ之强度}

一般に試片の寸法が小さい程その破碎限荷重は大きく，從つて戀 曲强度も大きく現はれる．實際に就て，同時に探つた多數の試片に ついての試驗結果を表示する.(加褧面一一表).

$\begin{array}{cccccc}\begin{array}{c}\text { 試片幅 } \\ \mathbf{c m}\end{array} & \begin{array}{c}\text { 支點間隔 } \\ \mathbf{c m}\end{array} & \begin{array}{c}\text { 厚 } \\ \mathbf{m m}\end{array} & \begin{array}{c}\text { 彎 曲 } \\ \mathrm{mm}\end{array} & \begin{array}{c}\text { 荷 } \\ \mathrm{kg}\end{array} \\ 5 & 30 & 1.95 & 9.7 & 3.89 & \begin{array}{c}\text { 重 } \\ \mathbf{k g} / \mathrm{mm}^{2}\end{array} \\ 4 & 25 & 1.88 & 8.5 & 4.14 & 11.0 \\ 4 & 20 & 1.87 & 6.2 & 4.71 & 10.1 \\ 2.5 & 15 & 1.88 & 3.6 & 4.43 & 11.3 \\ 2 & 10 & 1.90 & 2.3 & 6.21 & 12.9 \\ 1 & 5 & 1.88 & 1.8 & 8.42 & 17.9\end{array}$

同一條件の試片でもその大きさによつて强度はかくも著しい相違 を示し，特に $2 \times 10 \mathrm{~cm}$ 位に小さくなると急に强度が大きく現はれ る、それ故に空ガラスの强度を比較する場合には必ずその試片の大 きさ即ち寸法を一定にし且つそれを明示寸ることが必要であり， 邓 比較試驗を實施するには餘り小さい試片では各試片間の强度に偏差 が大きく現はれ易いから， $5 \times 30 \mathrm{~cm}$ 位の大きさが最も適當である. その意味に於て本試驗では試片の基準をこの寸法に探うたのである (A. J. Holland, W. E. S. Turner, J. Soc. Glass Tech., 1936, 20, 72)

\section{8. 加壓法の相違による强度の攀化}

彎曲强度を測定する場合.その荷重は，試片の幅全體に互るナイフ エッヂを以て加ぶ゙きものであるが，本試驗に於ては比較のため幅 $30 \mathrm{~cm}$ にも及ぶ幅廣き試片についても多數測定の必要あり, かかる 長いナイフェッヂの取付けは實驗裝置の取披上不便が多いので，本 報告の測定は寸べて金屬の尖端を以て一點で荷重（原力）を加へたの である.

云ふまでもなく空ガラスの如き試片に加塺するのに，一點でする のとナイフェォヂを以てするのとでは，試片に及ぼす加節の狀況に 相違あるべきは當然の事ではあるが, 實際種々實測の結果から推し， 加慰法の相違による强度の變化は，ガラス自體に存する各試片每の 强度の相違よりも寧ろ小であり, 且つ又本試驗の目的はフルコール 空ガラス製造に關係ある實際工業的な問題を範圍としてるるので女 るから, 敢て實驗の進捗に便宜の多い一點加壓法を探用した。

晌一點加塺法とナイフェッヂ加堅法とで强度にどれ程の相違があ るものかを參考のため次に表示する．但しここに使用したナイフェ ッデの長さは $45 \mathrm{~mm}$ である. 試料は云ふまでもなく大形の一枚ガ ラスから探りたる多數の試片を四分しその各組の平均値を示したの である.

\begin{tabular}{|c|c|c|c|c|c|}
\hline & 支點間隔 & $30 \mathrm{~cm}$ & 加 尉 & 表 & \\
\hline 加厴法 & $\begin{array}{c}\text { 試片幅 } \\
\mathrm{cm}\end{array}$ & $\begin{array}{l}\text { 厚 } \\
\min \end{array}$ & $\begin{array}{c}\text { 彎 曲 } \\
\mathrm{mm}\end{array}$ & $\underset{\mathrm{kg}}{\text { 荷 }}$ 重 & $\begin{array}{c}\text { 强 度 } \\
\mathrm{kg} / \mathrm{mm}^{2}\end{array}$ \\
\hline 點 & 5 & 2.02 & 10.4 & 4.48 & 9.90 \\
\hline ナイフ & 5 & 2.03 & 10.2 & 4.20 & 9.15 \\
\hline 點 & 10 & $1.94^{\prime}$ & 10.8 & 8.30 & 9.90 \\
\hline ナイフ & 10 & 1.94 & 10.6 & 7.54 & 9.02 \\
\hline
\end{tabular}

即ち一點加壓の强度はナイフ加㺿より常に幾らか大さくなつてるる ことが分るけれども，各試片每の强度を見るに一點加厴の中にはナ イフ加壓の平均强度より小さく現はれてるるものが幾つもあると去 ふ風に，加㕻法をナイフェッヂにしなければなら好云ふ嚴格な規 定は少くも空ガ ラスの彎曲强度測定には適用しなくてもいい樣に思 はれる. (松尾淔治郎; 旭确子試，昭 4, 第 19,48).

\section{9. 試片の採り方と强度との關係}

フルコール法で引上げられたるままの大幅の一枚ガラスから試片 第 2 圖 試片の探り方とその割 れの狀態(第 16,17 項參照)

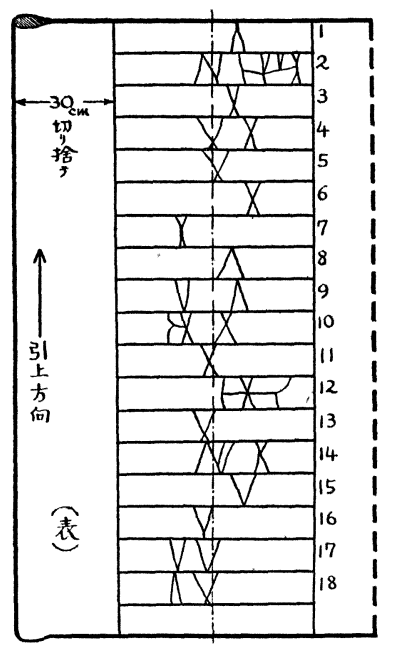

を探るに，そのガラスの引上 げ方向に對して橫に切り取つ たものと㹂に切り取つたもの とに於て强度に差があるかど らかを試驗した.試片の探り 方は第 2 圖の如く引上げガ スの一方の耳の部分には厚さ や表面狀態にムラがあるか ら，その部分約 $25 \mathrm{~cm}$ 幅だ け切り捨て，引上げガラスの 成るべく中央部正規の部分を 圖の如く横二列 16 枚, 竪二: 列 23 枚, 合計 39 枚を連續 切り取つて試片としたそその 結果を各列の平均及び全體の 平均值を以て示す。

郎ち横の二列と㹂の二列は 夫々各列共彎曲の度合及び强度に於て全く一致した值を示してるる

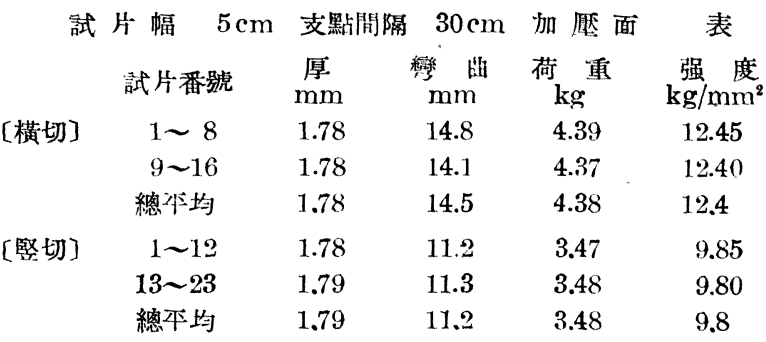

然るに橫列の强度と竪列の强度には可なりの相違が現はれてるる.

橫切り又は堅切りの相隣る二つの列の本均强度は常にこの樣に一 致するものか否かを更に他の試片に就て多數測定したところ，相隣 る二列でありながら著しく强度を異にする場合もあつた．郎ち次の 如き例がある。

$\begin{array}{cccccc} & \text { 試 片 數 } & \begin{array}{c}\text { 厚 } \\ \mathrm{mm}\end{array} & \begin{array}{c}\text { 彎 曲 } \\ \mathrm{mm}\end{array} & \begin{array}{c}\text { 荷 重 } \\ \mathrm{kg}\end{array} & \begin{array}{c}\text { 强 度 } \\ \mathrm{kg} / \mathrm{mm}^{2}\end{array} \\ \text { 〔横切】 } & 6 & 1.86 & 14.3 & 4.87 & 12.7 \\ & 6 & 1.77 & 17.3 & 5.19 & 14.9 \\ & \text { 本 均 } & 1.82 & \cdots & 5.05 & 13.9 \\ \text { [横切】 } & 9 & 1.91 & 9.4 & 484 & 8.5 \\ & 7 & 1.81 & 11.0 & 4.64 & 9.1 \\ & \text { 本 均 } & 1.86 & & 4.75 & 8.8\end{array}$

この結果から氣の付くことは，相隣る二列の厚さに凡そ $0.1 \mathrm{~mm}$ の差のあることであつて，その厚さの薄い列が絲曲の度大きく文强 度も大である。これは空ガラスが引上げられる際, 若し何かの理由 で厚さに不同が生ずると，その薄い部分が厚い部分に較べて强く急 冷を受けることになり，從つてその薄い部分に歪が强く生成されて るる筈であるから，その部分は薄いにも拘らず强度が大きく出るの であららと推察される．然し相隣る二列の間にかかる厚さの差なき ものでも强度に或る程度の相違を示すものもあるから，强度の一致 或は不同を生ずる原因は簡單には說明出來ない節がある。

次に前の方に杘り，橫切と㹂切との試片の强度に差のあることは 他の多數の實測結果からも常に認められる現象であつて，横切りの 列郎ちガラス引上げの方向に直角に切つた試片の平均强度は㹂切り 試片よりも常に大であつた. その本均值を列記するに次の如し.下 表の試片は云ふまでもなく夫々同一枚のガラスから㹂列橫列を同時 
に探つたもので，ガラスの製造洔期を晎にする 8 種の試驗結果を簡 單に列記したのである。その試片總數約 260 枚.

試片幅 $5 \mathrm{~cm}$ 支默閣隔 $30 \mathrm{~cm}$ 加盟面 表 横切列

\begin{tabular}{|c|c|c|c|}
\hline \multicolumn{2}{|c|}{ 横切列 } & \multicolumn{2}{|r|}{ 堅切列 } \\
\hline 厚 $(\mathrm{mm})$ & 强度 $\left(\mathrm{kg} / \mathrm{mm}^{2}\right)$ & 厚 $(\mathrm{mm})$ & 强度 $\left(\mathrm{kg} / \mathrm{mm}^{2}\right)$ \\
\hline 1.90 & 11.8 & 1.93 & 8.9 \\
\hline 1.84. & 11.1 & 1.86 & 10.4 \\
\hline 1.83 & 11.5 & 1.92 & 9.7 \\
\hline 192 & 11.9 & 191 & 10.3 \\
\hline 1.76 & 11.6 & 1.76 & 10.6 \\
\hline 1.81 & 13.9 & 1.82 & 11.0 \\
\hline 1.86 & 8.8 & 1.83 & 8.6 \\
\hline 1.78 & 12.4 & 1.79 & 9.7 \\
\hline
\end{tabular}

の樣に横切り列が强度大きく㹂切り列の强度小なる事實を元とし フルコール窓ガラス引トド操作の條件等を種々綜合して考へると次 第 3 阔

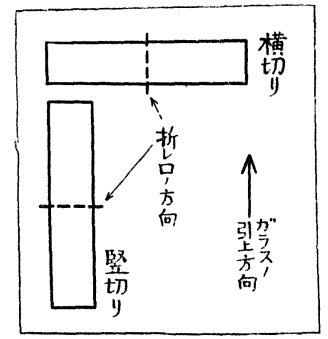
のやうな推定に想ひ賞る。

一般に空ガラス試片の强度に不同のあ るのはガラスの表面に䉰雜に flows ( 又 は zone of weakness) が分布存在して みるからで，その試片にかかる㧎笘ある 㭙その部分で破破寸るのであららと推察 しこれを俗に Flow theory と程する.

(A. A. Griffith, Ihit. Trans. Roy. Sac., 1920, 221 A , 163). 實際空ガラスの强度を 多数實測して見るとこんな假說でも設けないと說明のつけやうがな い事柄が頻りに起る。然るに茲に表示した如く同一枚のガラスから 橫切りと㹂切りの試片をとつて試驗すると必ず㹂切試片の强度は小 であると云ふ事實から，第3圖の圖解で分るやうに zone of weakness が鋻切り試片の折れ口の方向に本行に細かくガラスの內に存在して 西るのではないかと思はれる。竪切り試片の折れ口の方向は郎ち长 のガラス引上げ方向に直獬である゙，若しこの方向に細かく zone of weakness が本行に存在してるるものとすれば, 朢切りではその

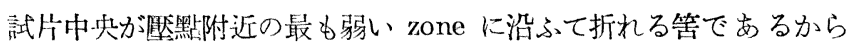
この場合一般に强度は小となつて現はれ, 反對に橫切り試片では試 片の長さに平行に强い zone と弱い zone とが並んで存在してるる から，その試片の强度は强い, zon"の程度に因り，從つて强度は當 然堅切りの時より大となる筈であると考へられる。

從つて本試驗に使用したるフルコール式引上げ空ガラスに於ては flowsは引上げ方问に直何の方向に細かく平行に存在してるると考 へれば上記の實測結果に說明がつくのである. 然らばこの flows が 何故引上方向に直角に生じてるるかと云ふその理訬や原因について は, 或る程度の推定は出來るが唒調査確認を要する點もあり, 几つ これは本報告の日的外のことであるから今はこの問題はこの程度に 止めて置く. 然し flows の存在はフルコール式空ガラ.スではいつで 当引上方向に直府であるとは速欮出來ない，作業狀況の相違等によ つて flows が竪横亂雜に生じてるることがあるか子知れない場合中 想像されるのである。

\section{0. 試片切口の牀龍之强さ}

試片を一定の寸法に切断する場合，荷重を加へんとする面にガラ ス切りを當てて切り取るべきか否か，而して又ガラス切りの當て方 を强くした時と弱くした時とに於て，試片の强度と割れ方とに相違 を示すものかどらかを明かにナるため次表に亦す如く種々の場合に 就て試驗した.

試片幅 $5 \mathrm{~cm}$ 支點闍隔 $30 \mathrm{~cm}$ 加磨面表

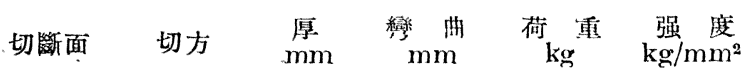

\begin{tabular}{|c|c|c|c|c|c|}
\hline 棐 & 弱 & 1.84 & 10.8 & 3.64 & 9.70 \\
\hline 表 & 强 & 1.83 & 10.1 & 3.58 & 9.62 \\
\hline 襄 & 弱 & 1.74 & 11.9 & 3.80 & 11.30 \\
\hline 裹 & 强 & 1.79 & 7.5 & 2.70 & 76 \\
\hline & 極强 & 1.83 & 6. & 34 & \\
\hline
\end{tabular}

郎ち表で切つたものは切月の强弱に拘らず强度は畍ば等しい値を 示したが，裏で切つたものは切方により强度に著しい差が現はれた 而して裏で極く强く切つた試片の强度は最小であつた、これは加筑 面が表の時であるが加筷面を裏にした時はどうなるかは次表に示ず 試片幅 $5 \mathrm{~cm}$ 芰點間隔 $30 \mathrm{~cm}$ 加算面 表

\begin{tabular}{|c|c|c|c|c|c|}
\hline 切斷面 & 切方 & $\begin{array}{l}\text { 厚 } \\
\mathrm{mm}\end{array}$ & $\begin{array}{l}\text { 䘎 曲 } \\
\mathrm{mm}\end{array}$ & $\begin{array}{c}\text { 荷 } \mathrm{c} \text { 重 } \\
\mathrm{kg}\end{array}$ & $\begin{array}{l}\text { 强 度 } \\
\mathrm{kg} / \mathrm{mm}^{2}\end{array}$ \\
\hline 表 & 弱 & 1.90 & 10.3 & 3.74 & 9.33 \\
\hline 表 & 强 & 1.83 & 6.9 & 2.43 & 6.52 \\
\hline 襄 & 弱 & 1.85 & 12.1 & 3.99 & 10.50 \\
\hline 裏 & 强 & 2.02 & 8.2 & 3.78 & 8.35 \\
\hline
\end{tabular}

卭ち裹から加重を加へた場合は切方の强弱によつて强度に著しい 差違が現はれた。

然し加䣑面の如何に拘らず切方を弱くしたものは一般に强度が大 きくなつてるるのは云ふまでもなく當然のことであるが，然らばこ

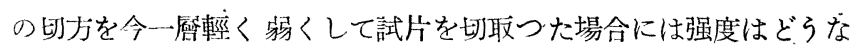
るかを更に他の試片について試驗した。 その結果は次の通りである 武片幅 $5 \mathrm{~cm}$ 支點間隔 $30 \mathrm{~cm}$ 切方極〈弱く

\begin{tabular}{|c|c|c|c|c|c|}
\hline 切瓶面 & 加些面 & $\begin{array}{l}\text { 厚 } \\
\mathrm{mm}\end{array}$ & $\begin{array}{l}\text { 彎 } \\
\text { mm }\end{array}$ & $\begin{array}{c}\text { 荷 }{ }^{\text {重 }} \\
\end{array}$ & $\begin{array}{c}\text { 强 慶 } \\
\mathrm{kg} / \mathrm{mm}^{2}\end{array}$ \\
\hline 表 & 表 & 1.86 & 10.6 & 3.74 & 9.73 \\
\hline 表 & 裹 & 1.85 & 10.7 & 3.63 & 9.54 \\
\hline 裹 & 裹 & 1.83 & 11.3 & 3.68 & 9.88 \\
\hline 裴, 裹 & 表 & 1.81 & 10.3 & 3.27 & 8.97 \\
\hline 表, 稟 & 裹 & 1.81 & 87 & 2.74 & 7.52 \\
\hline
\end{tabular}

上表の中「切斷面」の項に（表，裹）とあるは試片の一オを表で 切り他方を裏で切つたといふ意味である，郎ちかかる互違ひの面で 切斷したものは，一方の面だけで切つたものより稍弱くなのてるる 結局この三組の試驗結果及び總數 500 枚に上る試片についての試驗 結果を綜合して，切斷面がどちらであららとも切方を出來るだけ弱 く輕くして試片を切取ればその强度は畍将一定した值になることが 明かになつた。

それ故にダイヤモンドカッターを以て試片を切取る場合その切方 の如何がその試片の强度に可なりの影響を及ぼすこと, 從つて强度 試驗の試片は切方に深い熟練と細心の注意とを拂つたものでないと 本當の强度に近い值が出ない舛のであると，而して一般に力强く 亂暴に切つた空ガラスはその周緣の細かいヒビが原因となつて甚だ 割れ易いことを忘れてはならぬ.

少ここに云ふ切方の强弱輕重は實際の手心にあり，その切り目の 程度は數值で示すことは出來ず文寫眞で比較表示しても判然しない ものであるから，讀者に切方の狀態を理解してて員ふことは出來難い が，然しこの試驗に於る試片の切方は，良く切れる使ひ慣れたがイヤ モンドカッターを極く輕くガラスに當て, 搔き辛を出さぬ程度に静 かに引き搔き直ちに切り離つたものであること及びこの試驗に使用 した試片はすべて悉く著者自から一定の手心で切取つたるのであつ て，他の人に切取らしめた試片は一枚もないことを記すに止める. (A. J. Holland, W. E S. Turner; J. Soc. Glass Tech., 1936, 20, $279 ; 1934,18,225$ ).

以上記載の切口と强度との關係は空ガラスを實際に使用する場合 特に必要な事項であつて，空枠その他一定の寸法にガラスを切斷す る時成るべく輕く切つて使用すべきである事は以上の試驗結果から 容易に肯けることであると思ふ。實際空に嵌めてあるガラスを空枠 
の一邊からヒビを生じ或は割れた場合はそのガラスの切口が强く切 つてあつたか又は切れ難いガラス切りで下手に强く切つた䳩にその 切口のヒビから割れをた易く誘發したからであると推察されるので ある・

\section{1. 表面に切庭むる試片の强さ}

ガラス表面に故意にダイヤモンドカッターで種々樣々な切り目を 表或は裏につけて, 約 50 種の場合につき試驗した結果によれば,カ ッターで强く切れ目を入れたものでもその切日の方向によつては一 般に想像されてるる程試片の强さに著しい影響は認められなかつ た. 殊にガラスを正しく切斷し得る最小限度の輕さで試片の長さに 本行或は斜めに入れた切目は，それが表にあつても裏にあつても强 度に及ぼす影響は意外に僅少である. 但し加竺面の反對側へ，試片 の幅の方向に切目を大れるとその切目がどんなに輕微なもので僅 かの荷重でその切り目から直ぐ折れる. これはガラスを切斷する原 理に該當するから折れ易いのは當り前である. (A. H. Holland, W E. S. Turner; $J$. Soc. Glass Tech, 1937, 21, 383.).

切疵の影響を知る爲に一一例を次に表示する.

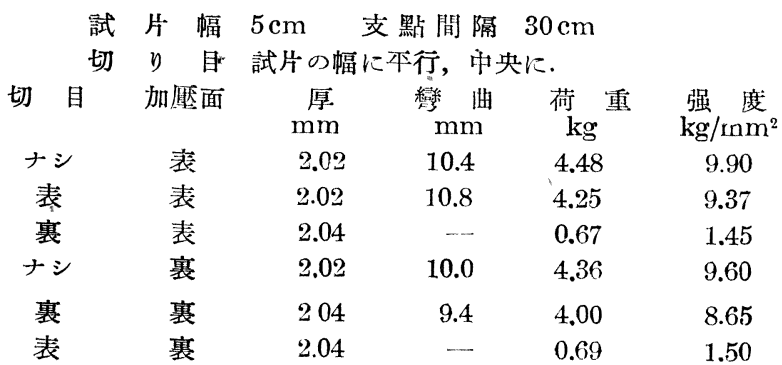

切疵が加壓面にある場合その試片の割方はその切齿の住無に拘ら ず一般に正常の割型を示すが，加壓面の反對側に幅に沿ふて切疵あ る場合は上記の如く $700 \mathrm{~g}$ で必ず切り目に沿ひ I 型に折れる.この 樣に故意につけた疵でさへその位置と方向により强度に及ぼす影響

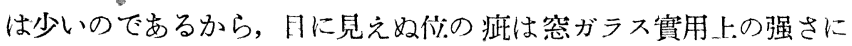
は殆ど關係がないと見做しても差支へない。

\section{2. 密カラスの表裏による强度の相違}

同一の熔融蠦に設置されてるる 4 基の引上機から引上げられたる ままの大形空ガラスを, 夫々の引上機から同時にとり，この 4 種の 大形試料から更に夫々試片を切取つて試驗した、試片の取方はガラ ス引上げの方向に長さ約 $35 \mathrm{~cm}$, 引上げ方向に直角の方向に幅正確 に $5 \mathrm{~cm}$ として, 大型空ガラスの一方の緣から他の緣へ連續順次切 斷したる短册型の試片を下記の枚數だけとり，更に各機につき夫々 二組に分け，一組は表より荷重を加へ，他の一組は裹の面に荷重を 加へ, 元の同一枚の空ガラスに表裏によつて强度に相違ありや否や を試驗した.その結果を 4 種各機の試片につき夫々平均して次に表 示する.

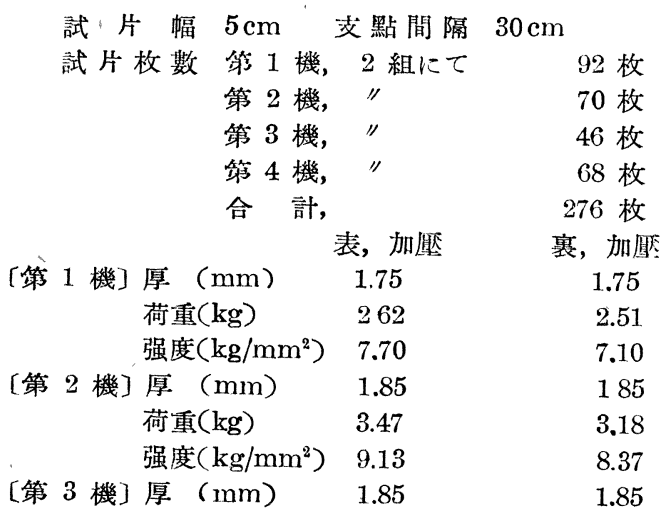

$\begin{array}{ccc}\text { 荷重 }(\mathrm{kg}) & 3.26 & 2.97 \\ \text { 强度 }\left(\mathrm{kg} / \mathrm{mm}^{2}\right) & 8.57 & 7.81 \\ \text { 「第 } 4 \text { 機] 愿 }(\mathrm{mm}) & 180 & 1.80 \\ \text { 荷重 }(\mathrm{kg}) & 2.79 & 2.73 \\ \text { 强度 }\left(\mathrm{kg} / \mathrm{mm}^{2}\right) & 7.75 & 7.58\end{array}$

これらの試片は同時に探取したのであるからそのガラス組成は殆 ど同一であり加工溫度等も等しいのであるが，引上機によつてガラ スの强度に些少の相違が認められる. この强度の相違は商品として 實用價值に影響を及ぼす程度のものには非ず，しかもこの些少の相 違は試片の取方々の他實驗設備に伴ふ誤差の他，その時の引上機の 調子の如何によるところが多いと考へられる。

次に試片の表裏による强度の相違は 4 機共例外なく裴の面に加獎 した時の方が强く現はれてるる．替ガラスでは後章第 44 項に記載 する如く支體間隔を一定にし試片の幅を變へて行くと，いづれの面 から加㕍しても略ぼ等しい强度を示す樣な寸法割合の默がある。こ の透板に於てもこれに似た性質があるかどらかを見る䉆に，支點問 隔を常に $30 \mathrm{~cm}$ とし試片の幅 $5 \mathrm{~cm}$ から $25 \mathrm{~cm}$ までのもの總計 77 枚に就て試驗した結果は次の如し。

\begin{tabular}{|c|c|c|c|c|c|}
\hline $\begin{array}{l}\text { 試片幅 } \\
\mathrm{cm}\end{array}$ & 加厢面 & $\begin{array}{c}\text { 厚 } \\
\mathrm{mm}\end{array}$ & $\begin{array}{l}\text { 彎 曲 } \\
\text { mm }\end{array}$ & $\begin{array}{l}\text { 荷 英 } \\
\mathrm{kg}\end{array}$ & $\begin{array}{l}\text { 强 度 } \\
\mathrm{kg} / \mathrm{mm}^{2}\end{array}$ \\
\hline 5 & $\begin{array}{l}\text { 表 } \\
\text { 裹 }\end{array}$ & $\begin{array}{l}1.91 \\
1.89\end{array}$ & $\begin{array}{r}12.3 \\
9.0\end{array}$ & $\begin{array}{l}4.26 \\
3.19\end{array}$ & $\begin{array}{r}10.50 \\
8.05\end{array}$ \\
\hline 10 & $\begin{array}{l}\text { 表 } \\
\text { 裹 }\end{array}$ & $\begin{array}{l}1.91 \\
1.88\end{array}$ & $\begin{array}{r}10.7 \\
9.5\end{array}$ & $\begin{array}{l}7.70 \\
6.26\end{array}$ & $\begin{array}{l}9.50 \\
8.00\end{array}$ \\
\hline 15 & 表 & $\begin{array}{l}1.85 \\
1.82\end{array}$ & $\begin{array}{l}9.4 \\
9.7\end{array}$ & $\begin{array}{l}9.02 \\
8.69\end{array}$ & $\begin{array}{l}7.92 \\
7.88\end{array}$ \\
\hline 20 & 表 & $\begin{array}{l}1.84 \\
1.80\end{array}$ & $\begin{array}{l}9.4 \\
8.6\end{array}$ & $\begin{array}{r}10.97 \\
9.81\end{array}$ & $\begin{array}{l}7.30 \\
6.82\end{array}$ \\
\hline 25 & $\begin{array}{l}\text { 表 } \\
\text { 裹 }\end{array}$ & $\begin{array}{l}1.80 \\
1.87\end{array}$ & $\begin{array}{l}7.0 \\
5.8\end{array}$ & $\begin{array}{l}9.81 \\
9.25\end{array}$ & $\begin{array}{l}5.45 \\
4.76\end{array}$ \\
\hline
\end{tabular}

即ち幅の大小に拘らず裴の面から荷重を加へた時常に强度大であ りこれは前表の結果と同一である. 而して幅ひろくなる程表亭强度 の差は次第に小となる傾向があるから，これより幅の大きいるので は表裏の强度は略ぼ等しぐなるかも知れないが，替板のや引に幅の 大小によつて表裏の强度が逆轉寸るやうな現象は見られない，

次に第 2 機の試料より試片の取方をそのガラスの引上方向に科に して連續切斷 8 枚をとり，关の結果を引上方向に平行に長くとつた 上記第 2 機の試片の結果と較ぺて見るに，略ぼ中間の强さを示して るることが分る．即ち次の如し．

[第 2 機の空がラス]

\begin{tabular}{|c|c|c|c|}
\hline $\begin{array}{c}\text { 试片探り方 } \\
\text { 加聇面 }\end{array}$ & $\begin{array}{c}\text { 引上方向 } \\
\text { 裹 }\end{array}$ & $\begin{array}{c}\text { 斜方 问 } \\
\text { 表 }\end{array}$ & $\begin{array}{c}\text { 引上方向 } \\
\text { 表 }\end{array}$ \\
\hline 厚 $(\mathrm{mm})$ & 1.85 & 1.85 & 1.85 \\
\hline 荷重 (kg) & 3.18 & 3.23 & 3.47 \\
\hline 强度 $\left(\mathrm{kg} / \mathrm{mm}^{2}\right)$ & 8.37 & 8.50 & 9.13 \\
\hline
\end{tabular}

以上の試驗結果を總括し空ガラスの彎曲强度の本均值を求むれば 大要次の通りである.

$\begin{array}{lc}\text { 試 片 } 276 \text { 枚 } & \text { 總 平均 } \\ \text { 厚导 } & 1.8 \mathrm{~mm} \\ \text { 破碎限荷重 } & 2.94 \mathrm{~kg} \\ \text { 變曲强度 } & 8.00 \mathrm{kgmm}^{2}\end{array}$

13. 一面を加熱しれる試片强度の變化

フルコール空ガラスの表裏强度に差のある理师を簡單に調べて見 第 4 圖 る.ガラスは一般に抗壓力

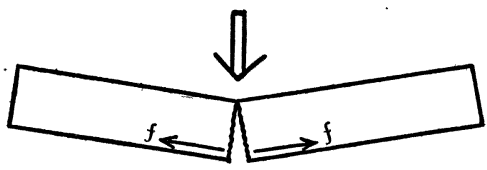
$\left(60--120 \mathrm{~kg} / \mathrm{mm}^{2}\right)$ 甚だ大 きく,これに較べて抗張力 $\left(3.5-10 \mathrm{~kg} / \mathrm{mm}^{2}\right)$ は甚だ小 である.而して窓ガラスが 荷重によつて折れる現象を常識的に考へて見ると，彎曲によるガラ 
ス表面表曆の張力（第 4 圖の f）がその點の抗張力より大となつた 洔その默に割れ口が生じ，その瞬間にガラス全體が破碎するものと 考へられる. 從つて彎曲强度とは, 荷重を加へる反對側の面のガラ スの抗張力を意味するとも考へられるから，ガラス表裏の抗張力に 相違ある場合には，當然その表裹により彎曲强度に相違を示す筈で ある.

平易に考へてこの抗張力はガラスが急冷されて分子排列が比較的 緊密である時大きく, 徐冷されて 分子排列が正常である時小である を常とするから，フルュール窓ガラスがデビトースのスロットから 引上げられる時そのガラスの裴裏に溫度の差があるか又は表裏の冷 却固化の速度に相違があつた場合には，その程度に應じて表裏の分 子排列に粗密の差を生じ, 從つて抗張力に相違が起つてるる筈であ る. 若しこの推察に誤りなしとすれば, かかる空ガラスを第 5 圖 (1)の如く抗張力大なる方を裹にして 加廖した洔は, 第 5 圖 (2) の如く抗 㲀力小なる方を裏にした時よりも破碎 限荷重は大となり, 從つて (1)の强度 は大きく現はれる筈である.

この推察を元にして次の如き實驗を 試みた。引上げたままの大形空ガラス
第 5 圆

(1)

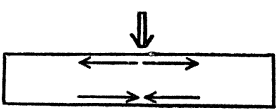

(2)

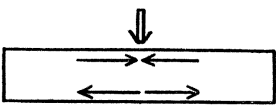

一枚を略ば六等分し，その各分より夫々試片 10 枚宛を探つた。而 して强度を測る時各試片の中央を表又は裏よりガス炤に當てて數秒 間急熱し，その加熱が裹側まで通らぬ先に，迅速に加崕して强度を 測つた. 而して加熱せず室溫のままに正常の方法で測つたものと比 較し，それらの平均值を表示するに次の通りであつた。

\begin{tabular}{|c|c|c|c|c|c|}
\hline 加熱面 & 荷重面 & $\underset{\mathrm{mm}}{\stackrel{\text { Pa }}{\mathrm{m}}}$ & $\begin{array}{c}\text { 彎 曲 } \\
\mathrm{mm}\end{array}$ & 荷 $\mathrm{kg}^{\text {重 }}$ & $\underset{\mathrm{kg} / \mathrm{mm}^{2}}{\text { 强 }}$ \\
\hline 七 ズ & 表 & 1.88 & 9.8 & 3.49 & 8.87 \\
\hline セ ズ & 袈 & 1.87 & 8.6 & - 3.08 & 7.92 \\
\hline 婊 & 表 & 1.90 & 10.4 & 3.63 & 9.04 \\
\hline 裹 & 表 & 1.90 & 8.9 & 3.21 & 8.00 \\
\hline 裹 & 裏 & 1.89 & 9.5 & 3.44 & 8.65 \\
\hline 表 & 裹 & 1.87 & 8.1 & 2.83 & 7.28 \\
\hline
\end{tabular}

この結果を試片の表裏と强度の順位に分り易く圖解して見れば第 6 圖の樣になる. 圖の中，矢印は加壓の方向，才は表，太線は加熱 面を六す。

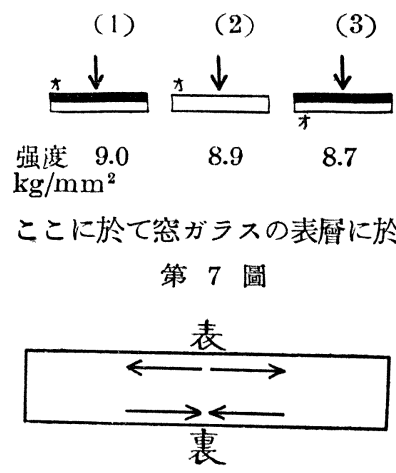
第 6 圖 に因る筀縮力に耐へることになるから，裏の壓縮力とにより彌々 强くなる譯である，これを裹返へしにして加算すれば反對に最も弱 くなる譯であつて，それは第 6 圖 (6) に該當するのである. (3)に 於ては哓の壁縮力が加熱によつて弱められるから（5）より强度は大 となることが推察され（4）はそれを裏返へしにしたものであるか ら（2）よりは弱くなることも推察し得るのである.

かやらにして窓ガラスを表から加壓した時常に强度が大きく現は れることと，ガラスの一方の面を加熱してガラス表厤に內在せる歪
力に變化を與へて測定した時の强度の變化と强度順位とから推察す るに，本試驗に探つたフルコール空ガラスの內部には本來第 7 圖 の如き狀態に歪力が分布してるるものと考へられるのである.

佮本試驗に使用した空ガラスの製造工場に於て引上裝置から出て 來る幅廣きガラス帶は一般に表の方に微かに凸出彎曲せんとする傾 向のあることが認められて居り，この彎曲は知張り第 7 圖 と同じ 傾向の歪力に原因寸ると考へられるから，製造現場で認められるガ ラス彎曲の倾向と，本試驗によつて推察される歪力の狀態とは明か に一致するのである.

フルコール空ガラスの內部にかかる否力が常に一定して存在する 理由は，フルコール空ガラスの製造行程を實際に就て觀察すれば理 解出來ることであるが，それは本報告の目的ではないから省略す る. 而してフルコールガラスの表と裏とにある歪の狀態は, 同じフ ルコール式製法でもその製造諸設備の相違と製造操作の如何によつ て相違することは推察に難くないのである.

これを要するに同一枚の大形板から切断して採つた相隣る試片の 間に强度の差あるは，如上の理由により主として試片にある䄳の强 弱及びその分布の狀態に基づくものと考へる外はない，事實空ガラ スの强度に關する報告文獻によるに組成と厚さが同一なる同形の試 片に於て充分アンニールを施して歪なきものは，歪あるりのよりは 强度小であり, 又極端に歪を大れた强化ガラスが强度大である事實 から考へても，窓ガラスの强度は主として歪の强弱とその分布の狀 態によつて相違を示すものと云ふべきであらう.(A. J. Holland, W. E. S. Turner; $J$, Soc. Glass Tech., 1934, 18, 225; 松尾值治郎, 旭 矿子試, 昭 4, 第 19，48). 從つて本試驗に使用したる相隣る位㯰に あつた試片の間に强さに差があり決して恒一の值を示さぬ事から推 して, 引上空ガラスの內には歪が可なり不規則に分布存在してるる ものと考へられるのである.

\section{4. 試片の厚さと强さとの關係}

厚さ $1.65 \mathrm{~mm}$ から $3.6 \mathrm{~mm}$ まで厚さの異るもの約 45 枚を選り出し その試片につき順次强さを試驗した結果は大要次の通りであつた.

彎曲强度の計算式によつて分るやうに，試片の幅と支點間隔が一 定であれば，その破碎限荷重は厚さの 2 乘に比例するものであるが 試みに實測の結果を圖表して見たところ，大體理論通りの曲線を示 した・而してその曲線を辿り, 各厭さに對する破碎限荷重の本均值 を求めたところ格ぼ次の如き荷重を得た。

$\begin{array}{lcc}\text { さ厚 } & \begin{array}{c}\text { 破碎限荷重 } \\ \mathrm{mm}\end{array} & \begin{array}{c}\text { 彎曲强度 } \\ \mathrm{kg}\end{array} \\ 1.7 & 2.5 & 7.8 \\ 2.0 & 3.3 & 7.4 \\ 2.5 & 5 . \mathrm{cm}^{2} \\ 3.0 & 7 & 7.2 \\ 3.5 & 9.4 & 6.9\end{array}$

試片の厚さが $1.65 \mathrm{~mm}$ の時と $1.9 \mathrm{~mm}$ の時とでは理論上それら の破碎限荷重は異り凡そ

$$
\begin{array}{ll}
1.65 \mathrm{~mm} & 2.2 \mathrm{~kg} \\
1.9 " & 3.0 "
\end{array}
$$

となつて厚さ $0.25 \mathrm{~mm}$ の相違に對し荷重が $0.8 \mathrm{~kg}$ だけ相違すべき 筈であるけれども，實際多數の試驗に於ては $1.65 \mathrm{~mm}$ 厚のものが 荷重 $2.3-3.2 \mathrm{~kg}$ を示し, $1.9 \mathrm{~mm}$ のものも $2.5-3.3 \mathrm{ko}$ を示すが如 く, 實際の破碎限荷重は決して一定の值を示さない，郎ち空ガラス に $0.2 \mathrm{~mm}$ 程度以下の差があつても, 餘程强い查でも無い限り破碎 限荷重は必ずしも厚さに比例した值を示すとは限らないから，從づ て厚さの僅かの相違は實際の强さに判然たる相違を現は寸程には影 響しないものであることが分つた 